\title{
Presenteeism in hospital nurses
}

\author{
Juliane Umann ${ }^{1}$ \\ Laura de Azevedo Guido² \\ Eliane da Silva Grazziano ${ }^{3}$
}

This quantitative, descriptive, cross-sectional research aimed to determine the estimated productivity of health-related limitations at work in 129 nurses working in direct care delivery to critical and potentially critical patients. Instruments were applied for socio-demographic and functional characterization and for the evaluation of presenteeism (Work Limitations Questionnaire). Statistical Package for the Social Sciences software was used for data analysis. In this study, $75 \%$ of nurses obtained a lost productivity index of up to $4.84 \%$. The physical demand domain represented the major limitation for these professionals (25\%). Presenteeism was directly correlated to health care, occurrence and number of absences, and indirectly related to work time at the unit. It was concluded that organizational or individual factors influence individuals' productivity, in view of the circumstances involving care delivery to critical and potentially critical patients.

Descriptors: Nursing; Occupational Health; Working Conditions; Stress Psychological.

\footnotetext{
${ }^{1}$ RN, M.Sc. in Nursing, Professor, Universidade Regional Integrada do Alto Uruguai e das Missões, Santiago, RS, Brazil. E-mail: juumann@hotmail.com.

${ }^{2}$ RN, Ph.D. in Nursing, Adjunct Professor, Departamento de Enfermagem, Universidade Federal de Santa Maria, RS, Brazil. E-mail: Iguido344@gmail.com.

${ }^{3}$ RN, Ph.D. in Nursing, Adjunct Professor, Departamento de Enfermagem, Universidade Federal de São Carlos, SP, Brazil. E-mail: grazzianoe@yahoo.com.br.
}

Corresponding Author:

Juliane Umann

Universidade Regional Integrada do Alto Uruguai e das Missões

Departamento de Enfermagem

Av. Batista Bonoto Sobrinho, $\mathrm{s} / \mathrm{n}$

Bairro: São Vicente

CEP: 97700-000, Santiago, RS, Brasil

E-mail: juumann@hotmail.com 


\section{Presenteísmo em enfermeiros hospitalares}

Este é um estudo quantitativo, descritivo e transversal com o objetivo de determinar a produtividade estimada das limitações no trabalho, relacionadas à saúde, em 129 enfermeiros atuantes na assistência direta a pacientes críticos e potencialmente críticos. Utilizou-se instrumento para caracterização sociodemográfica e funcional e para a avaliação do presenteísmo (questionário de limitações no trabalho). Procedeuse à análise estatística dos dados com o software Statistical Package for the Social Sciences. Neste estudo, 75\% dos enfermeiros obtiveram índice de produtividade perdida de até $4,84 \%$. A demanda física foi o domínio que representou maior limitação para esses profissionais $(25 \%)$. O presenteísmo correlacionou-se diretamente à realização de tratamento de saúde, ocorrência e número de faltas, e indiretamente ao tempo de trabalho na unidade. Conclui-se que existe influência de fatores organizacionais ou individuais na produtividade do indivíduo, frente às circunstâncias que envolvem a assistência ao paciente crítico e potencialmente crítico.

Descritores: Enfermagem; Saúde do Trabalhador; Condições de Trabalho; Estresse Psicológico.

\section{Presenteísmo en enfermeros hospitalarios}

Estudio cuantitativo, descriptivo y transversal con el objetivo de determinar la productividad supuesta de las limitaciones en el trabajo relacionadas con la salud de 129 enfermeros que asisten a pacientes críticos y potencialmente críticos. Se utilizó un instrumento para la caracterización sociodemográfica y funcional y para la evaluación de la presencia. Se realizó un análisis estadístico de los datos con el software Statistical Package for the Social Sciences. En este estudio, 75 \% de los enfermeros obtuvieron un índice de productividad perdida de hasta 4,84\%. La demanda física fue el dominio que presentó mayor limitación (25\%). La presencia se relacionó directamente a: realización de tratamiento de salud, ocurrencia y número de faltas, e indirectamente al tiempo en la unidad. Se concluye que existe influencia de factores organizacionales o individuales en la productividad del individuo frente a las circunstancias que involucran la asistencia al paciente crítico y potencialmente crítico.

Descriptores: Enfermería; Salud Laboral; Condiciones de Trabajo; Estrés Psicológico.

\section{Introduction}

Technological and socio-cultural development and the consequences of globalization grant benefits to the modern world and, on the counterpart, trigger changes in individuals' biopsychosocial behavior, directly interfering in the population's quality of life ${ }^{(1)}$. The requirements of capitalist dynamics in the labor world have also influenced the health sector(2).
Hence, the continuous technical and technological innovations and the requirements deriving from these changes in hospitals' work organization are perceived as conditions. As these frequently alter the job dynamics, they can affect workers' health to the extent that they go beyond these professionals' ability to adapt, entailing important repercussions for health work organization and the health workforce. 
In this context, nursing is present in hospital sectors that are considered exhaustive, due to the workload as well as the particularities of the tasks and range of functions performed(3).

The work routine, lack of control, impossibility to make work-related decisions, the limited support from peers and head have been indicated in research as characteristics and conditions that influence the stress process and/or affect nurses' well-being in the work environment ${ }^{(1,4-7)}$. In addition to these characteristics, the charge for greater productivity at work, associated with the reduction in staff and time to accomplish activities and the increased complexity of tasks can lead to tension, fatigue and professional exhaustion, representing factors responsible for occupational stress situations ${ }^{(6)}$.

The acknowledgement of the effects of work on the determination and evolution of workers' healthdisease process entails ethical, technical and legal implications, which affect the organization and quality of care delivery. Also, the damage caused to professionals' health represents economic costs, deriving from workers' abandonment and treatment, as well as decreased performance and productivity, and stand out as emerging conditions with negative effects for the organization $^{(8)}$.

Thus, the peculiar situations of the health work environment and the behavioral elements involved in the decision process, such as individuals' motivation and relation with work and their health-disease process, are factors related to absenteeism(9).

Absence from work due to disease, a process called absenteeism, entails a burden for those who continue at work, resulting from the need to perform absent workers' activities as well, which can lead to the appearance of new health problems and the possibility of future absences ${ }^{(10)}$.

In this context, as opposed to absenteeism, presenteeism designates the condition in which people attend the work environment but perform the activities inherent in their functions in a non-productive way, i.e. their performance is not good due to work-related physical and mental problems ${ }^{(5)}$. Presenteeism relates health problems and productivity loss, as a consequence of excessive work and the feeling of insecurity deriving from new work relations, characterized by high unemployment rates, restructuring of public and private sectors, decrease in organizational size, reduction in staff numbers, increased quantities of temporary workers and decreased benefits ${ }^{(11)}$.

In this perspective, establishing a relation between a certain health event - damage or illness - individual or collective, potential or installed, and a given work condition, represents the basic condition to put in practice Occupational Health actions in health services ${ }^{(12)}$.

Knowledge about work limitations permits surveying available internal and/or external resources and improving individual skills to cope with situations, considering both the illness and personal needs. Hence, the goal of this study was to determine the estimated productivity of health-related work limitations among hospital nurses.

\section{Methods}

This descriptive and cross-sectional study with a quantitative approach was developed at Hospital Universitário de Santa Maria (HUSM), a high-complexity public institution that is considered a regional health reference in the medical and hospital areas, aimed at care, teaching, research and community services.

Nursing care units at the institution were classified as open and closed, according to the patients' critical and potentially critical health condition. Critical patients are considered as: severe patients, one or more of whose physiological systems have been compromised, including loss of self-regulation, need for artificial function replacement and continuous assistance; and potentially critical as: severe patients, clinically stable, whose situation can worsen and who need continuous care ${ }^{(13)}$.

For this study, open units were considered as units that receive potentially critical patients, including: Medical Clinical Hospitalization Units I and II, Surgical, Toco-gynecological, Pediatric, Psychiatric, Emergency Care. Closed units are considered units where critical patients are attended, which are: adult, pediatric and neonatal Intensive Care Units, Intensive Cardiology Unit, Hemato-oncology Unit, Obstetric Center, Surgical Center and Anesthetic Recovery Room, Hemodynamics Laboratory and Nephrology Service.

The study population comprised 129 nurses working at those hospital units, selected according to the following criteria: nurses at public health services, active in direct patient care. Professionals on any kind of leave during the established data collection period were excluded. 
The research protocol was followed, which comprises an instrument for socio-demographic (birth date, gender, education, marital status, number of children, any current or past health treatment) and functional (weekly hour load, work experience, shift, work unit, absence from work due to illness in the previous year) characterization, besides the Work Limitations Questionnaire (WLQ) to assess presenteeism.

The $W L Q^{(14)}$ has been translated and culturally adapted and validated for the Brazilian reality(15), used to assess presenteeism based on the lost productivity measure, associated with the interference of health problems in work activity performance. The instrument comprises 25 items, grouped in four work limitation domains, which are: time management, physical demand, mental-interpersonal demand, and production demand.

Each item was scored as follows: no part of time (one point), a small part of time (two points), some part of time (three points), most of the time (four points) and the whole time (five points). WLQ domain scores range from zero (no limitation) to 100 (full-time limitation), indicating the percentage of time the individual was limited to perform activities at work.

Data were collected in March and April 2010. The nurses were approached individually. In compliance with the Guidelines and Regulatory Standards for Research Involving Human Beings (CNS Resolution 196/96), the research participants received an Informed Consent Term (ICT), which was presented; further clarifications about the research were provided and the term was signed. This project received approval from the Institutional Review Board at Universidade Federal de Santa Maria, under No 23081.016653/2009-08.

Statistical Package for the Social Sciences (SPSS - version 17.0) software was used for statistical data analysis. The Kolmogorov-Smirnov test was applied to check the data's normal distribution. Qualitative variables were described through absolute and relative frequencies, while medians and inter-quartile intervals were used for quantitative variables, as they did not attend to normal distribution. The relations between socio-demographic and functional data on the one hand and Work Limitations Questionnaire results on the others were established using Spearman's correlation coefficient and the Mann-Whitney test.

The internal consistency of the scale was assessed using Cronbach's Alpha Coefficient, with a view to checking the reliability of what the instrument intends to measure. Scores above 0.70 are considered confirmatory for this purpose ${ }^{(16)}$.

\section{Results}

Concerning the socio-demographic profile, female $(92.2 \%)$ and married (65.1\%) nurses prevailed, with children $(69.5 \%)$, holding a graduate degree $(89.9 \%)$ and without any current health treatment for $62.5 \%$. The mean age was 39.47 years, ranging from 25 to 63 .

As for functional characteristics, $41.9 \%$ of the workers work at night, $66.7 \%$ received training, $24 \%$ have another job; $77.5 \%$ work overtime. Absences were found in $38 \%$ of the nurses. Reasons varied from diagnosed diseases (23.3\%), family motives (11.6\%) and both $(3.1 \%)$. The mean hour load was 34.4 hours per week, with a 40 -hour week for $26.4 \%$ of the nurses. The mean professional experience at the institution and unit were 10.96 and 7.10 years of work, respectively.

The internal consistency of the WLQ was confirmed, based on Cronbach's Alpha Coefficients between 0.78 and 0.90. Non-normal distribution was found for WLQ scale scores.

The analysis of WLQ results reveals a lost productivity index of up to $4.84 \%$ for $75 \%$ of the nurses (Table 1).

Table 1 - Inter-quartile intervals for the WLQ. Santa Maria, RS, Brazil, 2011

\begin{tabular}{lccc}
\hline \multirow{2}{*}{ WLQ/domains } & \multicolumn{3}{c}{ Inter-quartile intervals } \\
\cline { 2 - 4 } & $\mathbf{2 5}$ & $\mathbf{5 0}$ & $\mathbf{7 5}$ \\
\hline WLQ index & 1.15 & 2.36 & 4.84 \\
Time management & 0.0 & 5.0 & 15.0 \\
Physical demand & 16.66 & 25.0 & 33.33 \\
Mental-interpersonal demand & 0.0 & 8.33 & 18.05 \\
Production demand & 0.0 & 0.0 & 15.0 \\
\hline
\end{tabular}

The analysis of medians reveals the greatest productivity loss in the physical demand domain (25\%). The median for production demand was zero, that is, half of the population did not indicate any productivity loss related to the ability to achieve the necessary quantity and quality of finished work in due time. Productivity loss percentages for time management and mentalinterpersonal demand equaled 5 and $8.3 \%$ (Figure 1). 


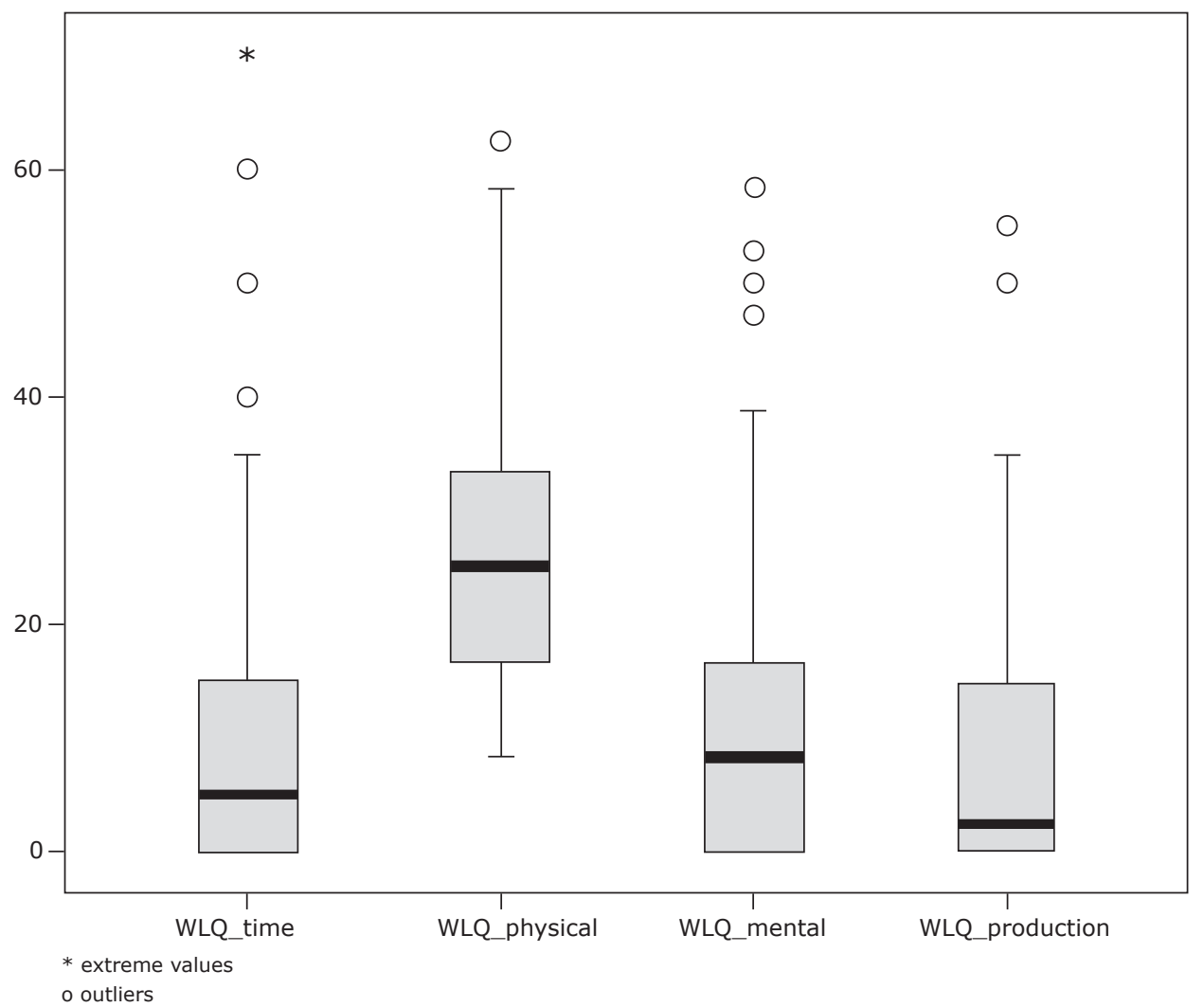

Figure 1 - Medians of WLQ scale results, Santa Maria, RS, Brazil, 2011

It is highlighted that $*$ and $\circ$ represent extreme values (values three times higher than the third quartile) and outliers (values 1.5 times higher than the third quartile), respectively, due to the non-normal distribution of scale data.

Concerning hospitalization units, WLQ scores range between 1.39 and $6.43 \%$, with open units showing a higher general lost productivity index (2.74\%) than closed units $(2.13 \%)$. The pediatric unit revealed the highest general lost productivity index among all units (6.43\%). The Hemodynamics Laboratory and Medical Clinic II, then, displayed the lowest general lost productivity indices, corresponding to 1.44 and $1.39 \%$, respectively.

The correlation between the WLQ and sociodemographic and functional variables resulted in direct and significant associations between the number of absences and the general scale index $(p=0.244)$, and also with the time management domain $(p=0.274)$. This result indicates that, the higher the number of absences, the greater the general productivity and time management loss. As for the correlation between the mental-interpersonal demand domain and the variable professional experience at the unit, a significant and indirect association $(p=0.177)$ was obtained, which means that, the longer the professional experience at the sector in question, the lesser the limitation for the accomplishment of cognitive tasks and the difficulty to interact with people at work.

Statistical differences were found between nurses who were absent from work or not, with nurses who were absent showing higher general lost productivity indices $(p=0.004)$, as well as for the physical demand $(p=0.03)$ and time management domains $(p=0.001)$.

Statistically significant differences were found for nurses with a current or past health treatment regarding time management $(p=0.047)$ and the general WLQ index $(p=0.023)$. Based on these data, the highest lost productivity indices were found for nurses undergoing a health treatment. Also, a trend towards greater productivity loss was found in the mental-interpersonal demand domain $(p=0.095)$ for professionals who reported a health treatment.

The relations between WLQ scores revealed that professionals who did not work overtime tended to obtain a higher general lost productivity index in comparison with nurses who did work overtime $(p=0.085)$.

No significant correlations were established between work shifts and WLQ scores. Hence, the work shift does not interfere in the assessment of lost productivity among nurses working in direct care delivery to critical and potentially critical patients. 


\section{Discussion}

Socio-demographic data for this population are similar to those found in national $(1,6,17)$ and international studies $^{(18-20)}$.

The analysis of presenteeism, assessed based on productivity loss, revealed an index of up to $4.84 \%$ for $75 \%$ of the nurses, so that the lost productivity percentage in this population can be considered low. Even if low, the productivity loss percentage indicates that interferences and consequences coexist subtly, for the service organization and institution as well as for professionals and care delivery. The inadequacy between work ability and the demand of the task to be performed influences productivity and its non-compliance can be a cause of exhaustion, discomfort, diseases and limitations related to the profession(21).

The physical demand domain represented the main limitation for the nurses in this study (25\%). The ability to perform tasks that require bodily strength, resistance, movement, coordination and flexibility was perceived as the most influential limitation for nurses' productivity loss. This result reveals the repercussion of the peculiarities involved in care delivery to critical and potentially critical patients for nurses' health, due to the patient and equipment mobilization requirements, transportation and maneuvering inherent in care to unstable patients.

Likewise, a study identified that, the more nurses' physical health is affected, the worse their psychological health, and the work ability drops considerably(21). The researcher justifies this result, considering that good physical and mental health and favorable work conditions sustain and enhance satisfactory work ability.

The production demand did not represent a limitation at work for half of the study population, i.e. these professionals showed no decrease in the ability to achieve the necessary quality and quantity of concluded work in due time. It is highlighted that, despite the appointed physical limitation, the nurses consider they perform the number of tasks with due quality and within the time available for this purpose. In that sense, the criteria based on which these professionals' assess care quality and even their perception and acknowledgement of their physical weakness for work are questioned, especially in sectors where patients' clinical instability constantly changes demands and requires a new order of priorities.

In this study, open units displayed a higher general lost productivity index than closed units. The pediatric unit obtained the highest general lost productivity index, while the Hemodynamics laboratory and Medical Clinic II presented the lowest. It can be inferred that, due to their physical and functional structure, surveillance and proximity at the open units are more limited, to the detriment of closed units, which is considered to contribute to the perception of decreased productivity. On the other hand, the historical culture of the nursing profession needs to be taken into account as, the greater the demand and number of tasks performed, the better these professionals' perceived output.

Nurses who were absent obtained higher general lost productivity indices $(3.78 \%)$, in the physical demand (29.17\%) and time management domains (5\%). By the way, the higher the number of leaves, the greater the general and time management-related productivity loss. It is important to consider that, in view of the percentage of leaves and number of lost workdays, the productivity loss is enhanced by the increased burden on team members who remain in the work environment, as demands need to be redistributed without impairing the critical and potentially critical patients' care needs.

In this study, the longer the professional experience at the specific unit, the lesser the limitation for the accomplishment of cognitive tasks and difficulties to interact with people at work (mental-interpersonal demand). Based on this result, it can be inferred that the setting, involving the stay and continuation in a given sector, can facilitate negotiation and adjustment to demands, due to the proximity of bonds established over time, and the possibility to request alterations that contribute to work performance. Besides, evidence exists that the increased flexibility of requirements to comply with work demands decreases the occurrence of

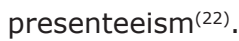

Higher lost productivity indices were found for nurses undergoing a health treatment. This demonstrates, despite the search to solve the problem, that physical and/or mental weakness interferes in output, compromises task efficacy in the work environment and can enhance risks and predispose to errors, impairing the quality of care delivery.

Nurses who do not perform overwork tend to reveal a higher general lost productivity index (3.78\%). This result may derive from the lack of need to organize and reorder tasks within the time available to attend to demands beyond common work hours. It is considered that professionals who work overtime not only challenge themselves, but also manage time better, in view of their lesser free time to perform the tasks they are 
responsible for. This can empirically justify these nurses' greater productivity in comparison with nurses who do not do overtime.

Based on these findings, presenteeism is considered to limit productivity in terms of work quantity, due to the decreased physical and mental output, as well as quality, due to the possibility of errors and reduced attention to work activities.

Productivity is a fundamental element in the job work, which influences the global economy. Assessments of this construct deserve special attention, mainly when involving health professionals, due to the specificity of the work process and its repercussions in the job context, involving interpersonal relations, satisfaction with work and the quality of care delivery.

\section{Conclusion}

Organizational and individual factors influence individuals' productivity in view of the circumstances involved in care delivery to critical and potentially critical adults. Special attention is due to physical limitations, appointed as responsible for greater productivity loss and for affecting nurses' health. Characteristics inherent in care delivery to unstable patients, insufficient resources and interpersonal relationship difficulties are conditions that can entail damage for these professionals' physical and mental health. The occurrence of leaves and health treatment should also be weighted, as they represent attempts towards health preservation and rehabilitation.

In a technical and technological reality whose occupational relations involve pressure, productivity demands and cost reduction, presenteeism is perceived as a negative condition for satisfactory economic output in organizations. Concerning health institutions, the product of work involves the promotion, rehabilitation and recovery of individuals' health and wellbeing. Therefore, workers at this sector deserve special attention, as benefits for society in general result from their (physical and intellectual) workforce.

Assessing presenteeism represents a challenge, as it is a non-palpable and seemingly hidden condition, which demands' professionals' acknowledgement of their condition to develop activities at work. Incorporating this reference framework into institutions' administrative levels is also considered a challenge, as this entails repercussions that often gain visibility through absences and leaves. Besides, measuring productivity directly is a hard task, mainly for jobs that demand mental and cognitive work, as it involves subjective factors.
These study results also contribute to advance multidisciplinary Occupational Health knowledge and supports the Nursing area, with a view to the planning of measures to promote and protect the health and wellbeing of professionals involved in direct care delivery to critical and potentially critical patients in the hospital context.

\section{References}

1. Jodas DA, Hadadd MCL. Sindrome de Burnout em trabalhadores de enfermagem de um pronto socorro de hospital universitário. Acta Paul Enferm. 2009;22(2):192-7.

2. Oliveira PR, Tristão RM, Neiva ER. Burnout e suporte organizacional em profissionais de UTI-neonatal. Educ Prof. 2006;1(1):27-37.

3. Batista KM, Bianchi ERF. Stress among emergency unit nurses. Rev. Latino-Am. Enfermagem. 2006;14(4):534-9. 4. Cavalheiro AM, Moura Junior DF, Lopes AC. Stress in nurses working in intensive care units. Rev. Latino-Am. Enfermagem. 2008;16(1):29-35.

5. Laranjeira CA. O contexto organizacional e a experiência de stress: uma perspectiva integrativa. Rev Salud Publica. 2009;11(1):123-33.

6. Schmidt DRC, Dantas RAS, Marziale MHP, Laus AM. Estresse ocupacional entre profissionais de enfermagem do bloco cirúrgico. Texto Contexto Enferm. 2009;18(2):330-7.

7. Ferreira LRC, De Martino MMF. Stress no cotidiano da equipe de enfermagem e sua correlação com o cronótipo. Estud Psicol. 2009;26(1):65-72.

8. Paschoal T, Tamayo A. Validação da escala de estresse no trabalho. Estud Psicol. 2004;9(1):45-52.

9. Primo GMG, Pinheiro TMM, Sakurai E. Absenteísmo no trabalho em saúde: fatores relacionados. Rev Med Minas Gerais. 2007;17 Suppl 4:S260-S8.

10. Primo GMG. O perfil dos trabalhadores, seu adoecimento e absenteísmo em um hospital público universitário [dissertação de mestrado]. Belo Horizonte (MG): Universidade Federal de Minas Gerais; 2008.110 p. 11. Sandí GF. Presentismo: potencialidad en accidentes de salud. Acta Med Costarric. 2006;48(1):30-4.

12. Ministério da Saúde (BR). Doenças Relacionadas ao Trabalho: manual de procedimentos para os serviços de saúde. Ministério da Saúde do Brasil. Brasília (DF): Conselho Nacional de saúde; Ministério da Saúde; 2001. [acesso 25 out 2009]. Disponível em: http://www.ims. uerj.br/espmedtrab/doenca_trabalhador.pdf 
13. Consulta Pública n. 21, de 27 de abril de 2006 (BR). Minuta de Resolução que define o regulamento técnico para funcionamento de serviços de atenção ao paciente crítico e potencialmente crítico. 2006. [acesso 22 out 2009]. Disponível em: http://www4.anvisa.gov.br/ base/visadoc/CP/CP\%5B14558-1-0\%5D.PDF

14. Lerner D. Amick BC, Lee JC, Rooney T, Roger WH, Chang $H$, et al. Relationship of employee-reported work limitations to work productivity. Med Care. 2003;41(5):649-59.

15. Soárez PC, Kowalski CCG, Ferraz MB, Ciconelli RM. Tradução para português brasileiro e validação de um questionário de avaliação de produtividade. Rev Panam Salud Publica. 2007;22(1):21-8.

16. Field A. Descobrindo a Estatística usando o SPSS. 2.ed. Porto Alegre: Artmed; 2009. 688 p.

17. Grazziano ES. Estratégia para redução do stress e Burnout entre enfermeiros hospitalares. [tese de doutorado]. São Paulo (SP): Escola de Enfermagem da Universidade de São Paulo; 2009. 232 p.

18. Tarrant T, Sabo CE. Role conflict, role ambiguity, and job satisfaction in nurse executives. Nurs Admin Q. 2010;43(1):72-82.

19. Denis S, Shannon HS, Wessel J, Stralford P, Weller I. Association of Low Back Pain, Impairment, Disability \& Work Limitations in Nurses. J Occup Rehab. 2007; 17:213-26.

20. Wu H, Chi TS, Chen L, Wang L, Jin YP. Occupacional stress among hospital nurses: cross-sectional survey. J Adv Nurs. 2010;66(3):627-34.

21. Costa JRA, Lima JV, Almeida PC. Stress no trabalho do enfermeiro. Rev Esc Enferm USP. 2003;37(3):63-71. 22. Bockerman P, Erkki L. Predictors of sickness absence and presenteeism: does the pattern by a respondent's health? J Occup Environ Med. 2010;52(3):332-5. 